\title{
The Efficacy of School Inspection and the Quality Teaching- Learning of Students in Lower Secondary Schools in Uganda
}

\author{
John Busingye \\ Ibanda University \\ P.O.Box 35 Ibanda Uganda
}

\begin{abstract}
ABSRACT
The study evaluated the efficacy of school Inspection upon quality teaching/learning in lower secondary Schools. The study targeted a population of 280 participants selected from twenty (20) schools with a sample size of 203 participants that was investigated. Questionnaires were the main data collection tool used. The study findings show that the geographical location of some schools, lack of enough finances to carry out inspection, bad weather conditions, heavy work load of duties by district inspector of schools and education officers. The study concluded that district education officers and inspector of schools were vital in the teaching learning processes. The study commends that there is need for excellent working relationship between the inspection team and classroom teachers through formal meetings to high light on the progress and challenges related to teaching/learning outcomes. The study further commends government to increase the budget allocated to lower secondary school inspection so as to inspire the inspection activities to be carried out as planned in the education sector.
\end{abstract}

Key words: School Inspection, quality teaching/learning and challenges

\section{INTRODUTION}

School inspection is professed as a practice of accountability in education system according to Benerjee (2007). School inspection has been used as a methodology of improving supervision, monitoring and evaluation of the quality of education standards by various countries worldwide. Chimombo (2005) agues from an Afrocentric point of view that inspection is as old as mankind in management and administration which is conceptualized as autocratic management targeting at apprehending the workers redhanded. A fault and a one- time fact finding action. Thus school inspection in Kenya and elsewhere in the sub-Saharan Africa seem to be viewed as a process of checking on class room teachers' work to ascertain if statutory and beaucratic regulations are tailed and that allegiance to the higher authorities are upheld. Viewing inspection of schools in this direction over stretches the interests and desires of the teaching /learning profession. Inspection methodological process conducted with this thinking in the minds of the teachers and inspector of schools may not be relevant in driving quality of teaching and improving teaching in secondary schools.

In Ghana school inspection system based on the educational assessment of the colonial rule -the British system. The role of inspectors in Ghana is to regulate the teachers and their performance in classroom (Grauwe, 2007). Likewise, the British contemplates school inspection as a methodology to monitor and evaluate progressive initiatives and extend guidance (OFSTED 2013). In the education sector in Uganda, inspectorate is one of the organs on the Ministry of Education structure. The Government of Uganda 
established the Directorate of Education Standards (DES) with the Ministry of Education and Sports (MoES) in 2008 whose main duty is to carry out school inspection, document and share best practices with in the education system and other related partners Mutabaruka (2018). The aim of achieving Inspectorate structure in Education Management System currently under the Directorate of Education Standards Agency (DESA) which is mandated to set standards and ensure quality of teaching MOES (2010). Nevertheless, this was to guarantee sustainable supervision, reviewing progress and inspection for quality assurance and enhancement a chance to reinforce application of the developed teaching instruction reforms to appreciate quality assurance and Minimum standards in secondary schools.

The upkeep of standards and assurance of acceptable quality control procedures are now a concern of all open-minded parents and all shareholders. The connotation of school inspection and supervision has now days come into the public interest. The State Policy on Education standards (NPES, 1981), focus on aims and objectives of education supervision as to ensure quality control through regular inspection and continuous supervision of educational institutions. In this respect it's vital for schools to adhere to regular supervision soastogiveadvice, guide, inspire to improve and supervise teachers and heads of schools to achieve their expectation. Educational supervision and inspection focus on teachers and delivery of teaching materials more than the students in high schools. The canon role of supervisors and or inspector of schools aims at supporting, helping, inspiring information sharing rather than commanding. Never the less supervision and inspection improves teacher efficacy. Teachers are guided on their duty roles, staff development, school organization patterns, special abilities possessed by the individual teachers and finally promotion (Mutabaruka 2018). Therefore inspection and supervision in secondary schools influences the quality of performance of individual teachers and educational institutions hence the quality of teaching- learning.

\section{STATEMENT OF THE PROBLEM}

The pertinent role of school inspection and supervision in Uganda is to promote quality assurance, efficacy and access to (MOES, 2016). The principle aim deals with setting systems, describing and oversee standards and quality of education and sports and to screen the success of such standards and quality to guarantee persistently better-quality education and sports in the country. Preferably, school inspection and supervision comprehends; regular institutional visits to monitor the progress of teaching-learning, sanitation, obtaining data on teachers and students daily attendance. It also entails discussion with teachers for improved teacher-learner performance so as to ensure policy execution (MOES, 2012). Ideally, steady school inspection should not only monitor efficacy of teaching-learning but also guarantee quality education pointers. Today, there is uneven school inspection, poor financing, few inspector of schools and education officers , and undependable means of transport, poor motivation, supervision and inspection. As a result, there is a public outcry in Uganda. Hence the purpose of this paper is to evaluate the influence of school inspection on quality teaching-learning in secondary schools. 


\section{LITERATURE REVIEW}

Learning is a dynamic processes which cannot take place without inspection of teachers in order to appreciate their work, observe learners closely to match school curriculum and teaching to learner's emerging capabilities, desires, and benefits, and then help students move forward by targeting educational experiences to the edge of students' changing dimensions so as to contest but not exasperate them. Learners are exceedingly enthused to understand what they almost, but not moderately, grasp and to major what they can virtually, but not moderately, do (Enderly, 2016). Victoria, (2019), states the process of school inspection and positioned herself to three objectives for conducting school inspection; One is report on the efficacy of education in schools and other educational foundations and to applaud deed for improvement; Two is to evaluate the arrangements for assuring quality in schools; and three to provide honest and unbiased instruction to the higher education authorities and to ensure that educational inventiveness are implemented excellently.

Billington and Clegg (2014) hold that Uganda's strategy for monitoring teaching and learning processes in schools and for enhancing quality and raising standards which has received a great deal of attention over the years concerns supervision by inspection. According to Billington and Clegg in reflecting on the practice of inspection by the Office for Standards in Education (OFSTED), the major purpose of inspection is "to gather data on a range of proof, match the proof against a statutory set of standards, arrive at verdicts and make those verdicts known to the public. Wanga, (2015), hypothesized inspection as overseeing, which involves guiding, regulating, dissemination, commanding, and other such actions that accentuate the task at hand and assess the extent to which particular objectives have been accomplished within the bounds, set by those in authority for their subordinates. Thus, School inspectors and education officers perform a vital role of taking a measure in improving learning through development of review strategies and syllabus throughout the Education system.

The motivating dynamism for the provision of school Inspectors and education officers was to endorse sustainable quality of education in developing communities like Uganda. Mekonnen, (2011),when replicating on the Uganda Education Act, noted that the key role of inspection in Uganda is to monitor the standards, quality, efficiency, and culture of the schools and to report to the state and the general public on these matters arising. Generally, the world trend of founding of school inspectors as educational chiefs was allied with efficiency delivery according to the quality pointers, ascertaining challenges faced in the system, assessing and revising strategies for better-quality performance and quality of education in general. The principle of learning is that students can perform things first in a helpful context and then later autonomously and in a variety of frameworks. Rogoff, (2014) pointed out that, the process of inspector-assisted learning as "guided participation" to emphasize that students actively collaborate with teachers to move to more complex ranks of understanding and skill is being comprehended as indicated in extraordinary academic performance of the learners.

Little, (2008) incorporated and reviewed Kajubi's report on education policy in Uganda, he qualified school inspectors for coordinated learning that has led to learners having the same curriculum for all religions which has guaranteed learners achievement as opposed to colonial government that introduced education in Uganda. During that time there was need for the state to put law and order in the way the protestant and Roman 
Catholic missionaries were founding schools. Protestant bosses were forcing all people to build protestant schools in their areas of jurisdiction. Similarly Roman Catholic bosses were forcing all people to build schools for the Roman Catholic in their areas of jurisdiction. As such education became denominational. Roman Catholic children were not allowed to attend protestant schools. In short no children were allowed to attend schools which were not being administered by their particular religious sect. This state of relationships crowned into a state of anarchy as some people started setting on fire some school buildings. This kind of lawlessness was one force which made the state to come in to direct educational development in the country and to introduce school inspection which has been so effective in emphasizing synchronized curriculum.

The Education Act, 2008, emphasizes the core role of Inspectors of school as to monitor learning/teaching achievement. This aspect justifies the importance of inspectors in effecting curriculum management for quality learning at school level. In this regard, supervises the teaching/learning process to learner's involvement and participation in concept appreciation. James, (2008) believed that, supervision is pertinent in improving standards in education, inspectors will know if the appropriate planning for instruction has taken place when the teacher is able to design a lesson that achieves the objective. This means everything the teacher and students do during lesson development is related to the objective. Rosenshine \& Stevens, (2009) indicated that the learning of facts is greatly facilitated when memories of organized principles and prerequisite concepts related to the lesson are reviewed at the beginning of the lesson. The prophylactic set as it is called by Abot (2005), requires the learner to overtly or covertly have the fundamentals in memory. The activity and or supervision is pertinent to guarantee that lessons are designed effectively to provoke information related to the lesson objective. During the opening it is important for learners to understand the direction of the tutoring, the significance of what they are learning, and to have a sense of continuity. Learners are often not able to see the correlation between today's work and the work from yesterday. Sharing the objective of the lesson informally with students would include teacher statements such as "what we are going to do today" and "the purpose for studying this notion." The lesson content includes the demonstration of facts. According to Rosenshine (2009) this is the explanation-demonstration stage of the lesson. To implement this segment of the lesson, inspectors should note that instructors have a wide variety of different styles and methods of teaching from which to choose. The larger the number of alternative teaching methods teachers is comfortable utilizing, the more likely they will select techniques that match the desired objectives, learning methods, and academic levels of their learners, which all come with effective supervision

Kim, (2002) emphasized, more than a hundred teaching methods whose attributes are common to all strategies. School inspectors are relevant to ensure that each teaching method with a set of its undertakings and role for the teacher and students are carried out. Each strategy has a logical sequence which is necessary if learners are to accomplish the lesson objective. Nevertheless, the selection of a teaching method is complex because there are numerous effective methodologies that could be applied, depending on the instructional goal. Lisa Barrow and Cecilis Rouse (2006) described from numerous teaching methods to organize the methods of instruction into four major classifications which they describe to as families of instruction. Holland, (2005), believes that learning philosophers and progressive psychologists have documented that human beings come to appreciate the world in various ways and that persons tend to select 
stronger model of teaching- learning. In Burahya county, most schools are lacking teaching materials and inspector's role on their provision is missing. This study will seek information leading to the understanding of the reasons why most schools lack teaching materials a midst school inspectors in Burahya county kabarole District.

\section{METHODOLOGY}

The research used a case survey study designs. It used a case study because 10 schools were selected for study. It is a survey because sampling for the schools and respondents was done within the selected schools (Greenberg, 2003). The targeted population comprised of all officials involved in inspecting secondary schools up to the District level. They included Head Teachers, Board of governors, c lass teachers, student leaders, the OB's and OGs of the of different schools, inspectors of schools, RDCs and local council leaders. All these categories of respondents were selected by the researcher because they were thought to be paramount in giving relevant information to this study. A total of three (3) secondary schools were selected from Burahya county in Kabarole district South West Uganda to participate in the study. A total population of 50 respondents were selected because this comprises the number of the people who are directly involved in school monitoring and inspection to ensure compliance to education standards. One Inspectors of school was selected. One head teacher and a Director of studies(D.O.S) from each secondary school was also selected for the study. One member of the school Board of governors, four teaching staff, two student leaders, two students from the old students association, one state representatives and two political leaders were also considered for the study. This therefore gives a total population of 12 respondents per school, giving a grand total of 36 respondents in 3schools. However, using Morgan and Krejcie (1970) table of sample size determination, out of the 53 respondents targeted in the 3 schools, a sample size of only 45 respondents was investigated. Therefore, purposive random sampling was employed to enable the researcher deal with people charged with the responsibility of supervising and inspecting District secondary schools both government aided and private secondary schools..

A questionnaire containing both closed and open ended questions designed and selfadministered to the respondents in order to get the relevant information. The data collected was edited and interpreted to remove errors and put similar responses together respectively. Data was entered in the SPSS (16.0) spreadsheet and thereafter cleaned and Edited for easy interpretation using narrative procedure. SPSS and excel packages were used to generate frequency distribution tables for purposes of easy interpretation of findings. 
Busingye, J. (2020). The Efficacy of School Inspection and the Quality Teaching-Learning of Students in Lower Secondary Schools in Uganda. Advances in Social Sciences Research Journal, 7(3) 303-311.

\section{RESULTS AND DISCUSSION OF FINDINGS \\ Measuring the effect of school Inspection on quality teaching-learning in secondary Schools}

Table.1 Effect of school inspection on the quality of teaching-learning

\begin{tabular}{|l|l|l|}
\hline \multicolumn{1}{c}{ Variable (s) } & \multicolumn{1}{c}{ Frequency (n=40) } & Percentage (\%) \\
\hline Learning entails supervision of teachers & 11 & 27.5 \\
\hline Absenteeism of learners is controlled & 06 & 15 \\
\hline Learners behavior is guaranteed & 12 & 30 \\
\hline My schools has enough teaching aids & 09 & 22.5 \\
\hline Others & 02 & 5 \\
\hline Total & $\mathbf{4 0}$ & $\mathbf{1 0 0}$ \\
\hline
\end{tabular}

How inspection affects the school syllabus $\quad$ Frequency $\quad(n=40) \quad$ Percentage $(\%)$

\begin{tabular}{|l|l|l|}
\hline Children also participate during inspection & 12 & 30 \\
\hline Teachers motivation is emphasized & 09 & 22.5 \\
\hline Relevance of school syllabus is stressed & 06 & 15 \\
\hline $\begin{array}{l}\text { Encourage co-curricular activities in } \\
\text { schools }\end{array}$ & 04 & 10 \\
\hline Others & 09 & 22.5 \\
\hline Total & $\mathbf{4 0}$ & $\mathbf{1 0 0}$ \\
\hline
\end{tabular}

Barriers to regular school inspections $\quad$ Frequency $(n=40) \quad$ Percentage (\%)

\begin{tabular}{|l|l|l|}
\hline Geographical location of some schools & 14 & 35 \\
\hline Geographical location of some schools & 10 & 25 \\
\hline Tight agenda of duties by school inspectors & 08 & 20 \\
\hline Bad weather conditions & 05 & 12.5 \\
\hline Others & 03 & 7.5 \\
\hline Total & $\mathbf{4 0}$ & $\mathbf{1 0 0}$ \\
\hline
\end{tabular}

\section{The efficacy of school inspection on the quality of teaching-learning}

Table 1 above shows the influence of secondary school inspection on the quality of teaching.

The study findings indicate that $27.5 \%$ learning requires supervision of teachers, $15 \%$ noted that Absenteeism of learners is controlled, $30 \%$ indicate that good behavior of learners is ensured, $22.5 \%$ suggested that schools have enough teaching aids while $5 \%$ believes that other factors that include focusing on the school syllabus among others.

On how inspection affects the school syllabus, the findings in Table.1 above, show that $30 \%$ of the participants believes that school inspection affects the syllabus by 
encouraging children to participate in the inspection exercise, $22.5 \%$ observed that teacher's motivation is emphasized, $15 \%$ relevance of subjects is emphasized, $10 \%$ consider emphasis on co-curricular activities in the syllabus while $22.5 \%$ noted other ways school inspection affects the syllabus coverage which includes scheduling of games and sports at the expense of academic work.

On barriers to regular school inspections, the table also shows the barriers to regular school inspections among schools in in Burahya county Kabarole District. The study findings indicate that $35 \%$ of the participants noted geographical locations of some schools, $25 \%$ limited resources to do inspection, $20 \%$ cited the tight schedule of duties by inspectors, $12.5 \%$ cited weather conditions while $7.5 \%$ of them cited other barriers that could include embezzlement of funds meant for inspection, late central government remittances among others.

\section{DISCUSSION}

According to the study findings, $27.5 \%$ of the participants believes that learning requires supervision of teachers, $15 \%$ noted that Absenteeism of learners is controlled, $30 \%$ noted that learners good behavior is ensured, $22,5 \%$ indicated that schools have enough teaching aids while $5 \%$ consider other factors that include focusing on the school syllabus among others. The findings of the study are in agreement with other scholars like White, (2015) who stressed that learning and development are long life processes and are dynamic.

Processes calls for inspection of teachers so as to appreciate the scale, perceive children closely to match syllabus and teaching to children's developing capabilities, desires, and benefits, and then help them advance by targeting educational experiences to the advantage of children's changing capabilities so as to test but not frustrate them. Human beings, particularly children, are highly rational to understand what they almost, but not quite, grasp and to dominate what they can almost, but not quite, do (White, 2015). The theory of learning is that children can do things first in a helpful context and then later individualistically and in different perspectives. White is in agreement with Rogoff, (2014) who contends that, the process of inspector assisted learning as "guided sharing" to accentuate that children actively collaborate with teachers to advance to more complex intensities of understanding and skill development as indicated in great academic enactment of the learners.

The Education Act, 2008 in Uganda specifies the principle role of Inspectors of school as to monitor learning attainment. As such it justifies the importance of inspectors in effecting syllabus management for effective learning at secondary school level. In this respect, supervises the teaching and learning process to determine children's participation and involvement in concept understanding. This is in agreement with Fredrick, (2010) who contends that, supervision is pertinent in improving education standards; inspectors are likely to tell if the suitable planning for instruction has taken place weather the teacher is able to design a lesson with specific and achievable objective. The implication is that activity the teacher and learners do during the lesson is related to the study objective. 


\section{CONCLUSION}

Inspectors of schools dramatize a pertinent role of guaranteeing that learners are prepared, presented, measured and evaluated and have self-motivation. One of the aspects of quality teaching that they inspect is ability of the teacher to plan for the subjects/activity particularly throughout the term. The cordial work relations between the different actors are characterized by regular formal and informal meetings to discuss progress in relation to teaching-learning attainment of outcomes in the face of school inspectors. Nevertheless, poor geographical locations of some schools hinder routine school inspection. Limited resources to do inspection, the tight schedule of duties by inspectors, bad weather conditions and other barriers that include diversion of funds intended for school inspection, delayed government remittances among others should be stressed.

\section{RECOMMENDATIONS}

The central government ought to raise the budget allocated to lower secondary school inspection so as to improve on the activity so that the education department of the local government at District level can fulfill the planned duties in a given term and time framework.

The ministry of finance planning and development should endeavor to guarantee that the funds intended for lower secondary school inspection is dispatched in time in order to make the activity a successful one.

Government should train other stakeholders i.e. Head Teachers, senior teachers and members of the board of governors with supervision skills in measurement and evaluation to strengthen the chain of inspection at lower secondary schoollevel.

The central government should construct and maintain feeder roads in the rural areas for easy access of school inspectors and any other government authorities like Resident District commissioners, commissioners of education among others.

Salaries, allowances and upkeep of school inspectors and lower secondary school teachers managers and all those involved in the monitoring and implementation of educational policies should be increased such that they are motivated to worker harder to improve their inspection services and teachers to improve teaching and selfevaluation in the rural schools. Special fund should be reserved for both the teachers and inspectors of schools working in hard to reach rural areas like Kasenda, karangura,and Kabende subcounties, Burahya county, Kabarole District South West Uganda.

\section{References}

Abot, I.(2005). Sustance use among students and out of school use in urban areas of Nigeria. W.H.O Geneva.

Benerjee, M.E.(2005)’Remedying Education: Evidence from two randomized Experiments in India'Quarterly journal of economics $122(3)$

Chimombo,J, (2005). Issues in basic educationin developing countries: an exploration of policy options for an improved delivery. Journal of international cooperation in education,8(1)121-152.

Enderly, M.N ( 2016) Teachers' perception and and practice of automatic promotion in English speaking primary schools in Cameroon. British journal of Educatioin,vol.4 No.11, Paper 11-23, October 2016. 
Fredrick, J. A. \& Alfeld, C (2010). Developing and fostering Passion in Academic and Non A cademic Domains. Gifted children. Quarterly 54(1)

Greenberg, J \& Baron, R,A, (2003). Behavoiur in Organisation, 8th edition. Prentice Hall. New york Jersey.

Gentile Weil (2000). Observational skills for effective teaching. Columbus, OH: Merrill. Grauwe (2007). Transforming School Supervision into a Tool of Quality Implementation.

Holand $\mathrm{H}$ (2005). Enhancing the benefits and overcoming the pitfalls of goal setting. Organizational Dynamics, 35(4), 332-340.Houston (Ed.): Handbook of research on Teacher Education. New York:

James, M.C( 2008). Parents educational background, their involvement and children's academic achievement. Journal of economic literate classification. Vol. 12 No. 2 pp 114-210.

Kim, E. (2002). The relationship between parents' involvement in management and students' Educational Achievement in the Korean Immigration Family. Journal of comparative Family studies, Vol, 33(4)pp5299(15)

Little J W. (2008) Real teachers, real classrooms and real experiences: The work of associates with preservice teachers on practicum. A Thesis for the Degree of Doctor of Education: University of Auckland, Macmillan.

Lisa Barrow \& Cecilis Rouse (2006). How parents supervision affects educational attainment. Journal of opportunities in America. Vol.116 No 2 pp 120-130

Mekonen, D (2011). The views of teachers and parents on the practices of automatic class promotion policy in Ethiopian primary schools. Hiroshima. Centre for the study of International cooperation in Education, Hiroshima University.

Ministry Of Education and Sports (2012). The Progress Made and Challenges Faced by the Education and Sports Sector: Kampala Uganda

Ministry of Education and Sports (2013). Department of Secondary Education: The Secondary Sub-Sector, Kampala Uganda

Ministry Of Education and Sports (2016). The Education and Sports Sector Annual Performance Report: Verification of Teacher Presence in Public Primary Schools. Kampala Uganda.

Ministry of education and sports. (2008). Education Act: Kampala Uganda

Morgan \& Krejcie (1970). Determining Sample Size for Research Activities: University of Minnesota. Duluth. Neave (1987). School Inspection with its Influence in the Quality

OFSTED (2013).The Framework of Inspecting Schools in England under Section Five of the Education Act 2005 (as amended).

Rogoff W (2014) The role of dialogue and self - assessment in improving student learning. Draft paper presented at the British Educational Research Association Annual Conference, Queen's University of Belfast, Northern Ireland

Rosenshine (2009) Techniques in the clinical supervision of teachers (2nd ed.). White Plains, NY: Longman.

Rosenshine B., \& Stevens, R (2009). Use of advance organizers in the learning and retention of meaningful Teaching and Teacher Education. 17, 819-836. Verbal material: Journal of Educational Psychology, 51, 267-272

Victoria (2019).Designing, Implementation and Performance Measurement System University of Cambridge, UK.

White R (2015). The effects of participation in teacher research on teacher efficacy. 